\title{
Ovarian Soft Tissue Neoplasm
}

National Cancer Institute

\section{Source}

National Cancer Institute. Ovarian Soft Tissue Neoplasm. NCI Thesaurus. Code C5244.

A benign or malignant soft tissue neoplasm of the ovary. Representative examples

include myxoma, fibroma, and sarcoma. 